\title{
Empirical Evidence on Corporate Governance in Europe: The Effect on Stock Returns, Firm Value and Performance
}

Citation for published version (APA):

Bauer, R. M. M. J., Günster, N. K., \& Otten, R. R. A. E. (2004). Empirical Evidence on Corporate Governance in Europe: The Effect on Stock Returns, Firm Value and Performance. Journal of Asset Management, 5(2), 91-104. https://doi.org/10.1057/palgrave.jam.2240131

Document status and date:

Published: 01/01/2004

DOI:

10.1057/palgrave.jam.2240131

Document Version:

Publisher's PDF, also known as Version of record

\section{Please check the document version of this publication:}

- A submitted manuscript is the version of the article upon submission and before peer-review. There can be important differences between the submitted version and the official published version of record. People interested in the research are advised to contact the author for the final version of the publication, or visit the DOI to the publisher's website.

- The final author version and the galley proof are versions of the publication after peer review.

- The final published version features the final layout of the paper including the volume, issue and page numbers.

Link to publication

\footnotetext{
General rights rights.

- You may freely distribute the URL identifying the publication in the public portal. please follow below link for the End User Agreement:

www.umlib.nl/taverne-license

Take down policy

If you believe that this document breaches copyright please contact us at:

repository@maastrichtuniversity.nl

providing details and we will investigate your claim.
}

Copyright and moral rights for the publications made accessible in the public portal are retained by the authors and/or other copyright owners and it is a condition of accessing publications that users recognise and abide by the legal requirements associated with these

- Users may download and print one copy of any publication from the public portal for the purpose of private study or research.

- You may not further distribute the material or use it for any profit-making activity or commercial gain

If the publication is distributed under the terms of Article $25 \mathrm{fa}$ of the Dutch Copyright Act, indicated by the "Taverne" license above, 


\title{
Empirical evidence on corporate governance in Europe: The effect on stock returns, firm value and performance
}

Received: 22nd September, 2003

\section{Rob Bauer}

is Manager of the Research Department of ABP Investments and Associate Professor of Finance at Maastricht University, The Netherlands. His present research focus is on asset liability management, risk budgeting, corporate governance, socially responsible investing, stock selection modelling and style analysis.

\section{Nadja Guenster*}

is working as a researcher for the Erasmus University Rotterdam, The Netherlands. Her research interests are corporate governance and socially responsible investing.

\section{Rogér Otten}

is Assistant Professor of Finance at Maastricht University, The Netherlands. He holds a PhD in Finance from Maastricht University. His main research topics include mutual fund investments, corporate governance and socially responsible investing.

${ }^{*}$ Rotterdam School of Management, Department of Financial Management, Erasmus University Rotterdam, Postbus 1738, 3000 DR Rotterdam, The Netherlands

Tel: +31 10 4082762; e-mail: nguenster@fbk.eur.nl

\begin{abstract}
This paper analyses whether good corporate governance leads to higher common stock returns and enhances firm value in Europe. Throughout, this study uses Deminor Corporate Governance Ratings for companies included in the FTSE Eurotop 300. Following the approach of Gompers et al. (2003, 'Corporate Governance and Equity Prices', Quarterly Journal of Economics, 118, 107-55), portfolios are built consisting of well-governed and poorly governed companies and their performances are compared. The impact of corporate governance on firm valuation is also examined. The results show a positive relationship between these variables and corporate governance. This relationship weakens substantially after adjusting for country differences. Finally, the relationship between corporate governance and firm performance is analysed, as approximated by net profit margin and return on equity. Surprisingly, and contrary to Gompers et al. (2003), a negative relationship is found between governance standards and these earnings-based performance ratios for which possible implications are discussed.
\end{abstract}

Keywords: corporate governance, asset pricing, equity returns, firm value, performance attribution, profitability ratios

\section{Introduction}

Promoted by corporate scandals such as Enron and WorldCom in the US,
Marconi in the UK and, most recently, Royal Ahold in the Netherlands, corporate governance has received a lot 
of attention in the financial community.

Institutional investors have started evaluating what role corporate governance should play in their investment policies. The McKinsey 'Global Investor Opinion Survey' shows that 15 per cent of European institutional investors consider corporate governance to be more important than a firm's financial issues, such as profit performance or growth potential. Additionally, 22 per cent of European institutional investors are willing to pay an average premium of 19 per cent for a well-governed company. ${ }^{1}$ Although this evidence demonstrates the interest in corporate governance, the important question of whether good corporate governance leads to higher stock returns and consequently to higher firm valuations has received limited attention in the academic literature.

For the US market, Gompers et al. (2003) analyse the relationship between corporate governance and long-term equity returns, firm value and accounting measures of performance. Their results clearly support the hypothesis that well-governed companies outperform their poorly governed counterparts. Well-governed companies have higher equity returns, are valued more highly, and their accounting statements show a better operating performance. These findings should encourage investors in US companies to consider corporate governance in their investment decisions.

Relatively few studies on this issue have investigated the European case. This paper is intended to fill this gap.

Following Gompers et al. (2003), it builds portfolios consisting of well-governed companies and compares their long-term equity returns with portfolios composed of poorly governed firms adjusted for style, country and sector exposures. Subsequently, the impact of corporate governance on firm valuation as measured by Tobin's $q$ is examined. Finally, the effect of corporate governance on firm performance is analysed. Two earnings-based ratios are used to approximate firm performance: net profit margin (NPM) and return on equity (ROE).

Although similar hypotheses to those of Gompers et al. (2003) are examined, the research design differs in various respects. This is mainly due to the different dataset available for Europe. Since the dataset consists of two currency areas, the UK and the European Monetary Union (EMU), it was decided to analyse them separately. Besides, this approach gives significant insight regarding the different impact of corporate governance in these two regions. Throughout this research, the corporate governance ratings of Deminor, which cover most companies included in the FTSE Eurotop 300, will be used. An advantage of this dataset is that Deminor is evaluating approximately 300 different governance criteria per firm. Therefore, the data provide a very comprehensive description of each firm's governance system. The main drawback, however, is that ratings are only available for two years, 2000 and 2001. To overcome this problem, the analysis is extended backwards, assuming constant governance ratings for a limited number of years. As shown in the data description below, this approach seems reasonable.

The remainder of this paper is organised as follows. The next section briefly summarises the empirical research on corporate governance. The third section provides a description of the database that is used throughout the analysis. In the fourth section, the main empirical results are presented. Finally, conclusions are drawn, and the implications of the results for investors are discussed. 


\section{The empirical corporate governance literature}

This brief survey of prior empirical research is structured along three lines. First, research on the relationship between long-term equity returns and corporate governance is discussed. This is followed by an overview of empirical research on the association between corporate governance and firm value. Finally, the impact of corporate governance on firm performance is examined.

Two closely related academic studies focusing on corporate governance and long-term equity returns are by Gompers et al. (2003) and Drobetz et al. (2004). Gompers et al. (2003) analyse the impact of 24 governance provisions on stock returns for about 1,500 US firms from 1990 to 1999 . They construct portfolios consisting of firms with numerous anti-takeover amendments ('Dictatorship Portfolio') and portfolios including firms with very few amendments ('Democracy Portfolio'). Subsequently, they examine the returns to holding a long position in the Democracy Portfolio and a short position in the Dictatorship Portfolio. This long-short strategy yields an average annual return of about 8.5 per cent after adjusting for factor exposures of the portfolios using the Carhart (1997) model. Drobetz et al. (2004) analyse the impact of corporate governance on stock returns over the period 1998-2002 in Germany. Owing to the fact that their corporate governance data are limited to one observation, March 2002, they assume constant historical ratings. To construct their sample, Drobetz et al. (2004) sent out questionnaires to 253 German firms in different market segments and received answers from about 36 per cent of these firms. In line with Gompers et al. (2003), Drobetz et al. (2004) also build factor portfolios consisting of well-governed versus poorly governed firms. After accounting for different factor exposures of the portfolios, their results show an amazing annual excess return of 16.4 per cent to a corporate governance long-short strategy.

The empirical literature on the relationship between firm value and corporate governance usually analyses either differences between countries and their impact on firm value or inter-firm variation within a country. The most prominent example of the first type of study is LaPorta et al. (1999), who investigate differences in governance standards among 27 countries. Their evidence shows that firms incorporated in countries with better governance standards tend to have a higher valuation. Examples of the second type of studies investigating inter-firm variation within one country are Drobetz et al. (2004) for Germany, Gompers et al. (2003) for the US, De Jong et al. (2001) for the Netherlands and Black (2002) for Russia. These studies generally find a positive relationship between governance standards and firm value. Comparing the findings of these studies, it is worth noting that the relationship seems to be stronger in countries with less developed standards.

There is rather less empirical literature which examines the impact of a complete set of governance standards on firm performance approximated by profitability ratios. Most studies instead investigate the impact of a single governance characteristic on firm performance. Again, the approach of Gompers et al. (2003) is followed. Their evidence shows that superior governance standards positively affect firm performance as measured by NPM and ROE in the US.

\section{Data description}

Deminor's corporate governance ratings are used to measure the companies' quality of governance. The ratings cover between 249 and 269 firms included in 
the FTSE Eurotop 300 over the period 2000-01. They are based on about 300 different criteria, which can be attributed to four broader categories: 'Rights and Duties of Shareholders', 'Range of Takeover Defences', 'Disclosure on Corporate Governance' and 'Board Structure and Functioning'. In turn, a short overview of each category is given and some descriptive statistics are shown, which give considerable insight into the characteristics of the data.

Within the first category 'Rights and Duties of Shareholders', Deminor evaluates whether shareholders can exert sufficient power to determine corporate action. Deminor assesses, for instance, whether the voting structure of the company and its procedures are favourable for shareholders. Shareholders should be able to file items on the agenda and counterproposal before as well as during the General Meeting. Further, according to Deminor's standards, the pre-emptive rights of existing shareholders should be guaranteed to ensure that their voting power cannot be diluted. The second category 'Range of Takeover Defences' evaluates whether the likelihood of a hostile take-over is significantly decreased by the adoption of anti-takeover amendments. According to Deminor's rating standards, incumbent management should not be able to block a take-over attempt at the expense of shareholders. Category three 'Disclosure on Corporate Governance' measures whether shareholders are able to obtain convenient and comprehensive information about the company's financial matters as well as its governance characteristics. For instance, the firm should release information on their board members, structure and committees as well as its remuneration and stock option plans. Within category four, Deminor analyses the firm's board structure and functioning. Important evaluation criteria in this category are the composition and election of the board members as well as remuneration and functioning.

To examine whether companies performing better in one of these categories also tend to outperform with respect to another category, the cross-sectional correlations of the four different categories are analysed. With the exception of 'Rights and Duties of Shareholders', all categories are significantly correlated. As expected, all categories are also significantly correlated with the total rating. These results clearly show that superior (or inferior) governance standards tend to persist across different dimensions. This paper will therefore focus on the companies' overall governance rating.

Governance standards do not only seem to be persistent across different dimensions, but also over time. The time-series correlations of the four categories as well as the total rating are well above 0.8 and significant at the 1 per cent level. Despite the fact that it would obviously be an improvement to have data available for a longer time horizon, these findings support our assumption of constant relative governance ratings over time. Throughout the empirical analysis, the 2000 ratings will be employed backwards until 1997 to obtain meaningful results. ${ }^{2}$

To explore whether sectors or countries differ between each other with respect to their governance standards, Tables 1 and 2 present sector and country averages, respectively. It is interesting to note that there are large and statistically significant differences between countries. Differences between sectors remain rather small. These findings suggest that corporate governance is strongly determined by country law. Throughout the empirical analysis, country as well as sector effects will be adjusted for. Although sector 
Table 1 Sector deviations

\begin{tabular}{|c|c|c|c|c|}
\hline Industry & $\begin{array}{l}\text { Mean } 2000 \\
\text { (t statistic) }\end{array}$ & $\begin{array}{l}\text { No. of } \\
\text { observations } \\
\text { in } 2000\end{array}$ & $\begin{array}{l}\text { Mean } 2001 \\
\text { (t statistic) }\end{array}$ & $\begin{array}{l}\text { No. of } \\
\text { observations } \\
\text { in } 2001\end{array}$ \\
\hline Basic Material and Energy & $\begin{array}{c}20.37 \\
(0.83)\end{array}$ & 25 & $\begin{array}{c}22.01 \\
(0.77)\end{array}$ & 25 \\
\hline Consumer Cyclical (Auto \& Cyclical Goods) & $\begin{array}{l}18.26 \\
(-0.85)\end{array}$ & 25 & $\begin{array}{c}19.22 \\
(-1.35)\end{array}$ & 25 \\
\hline Consumer Cyclical (Media \& Retail) & $\begin{array}{c}20.37 \\
(0.85)\end{array}$ & 23 & $\begin{array}{c}22.53 \\
(1.06)\end{array}$ & 27 \\
\hline Consumer Non-Cyclical (Good \& Services) & $\begin{array}{l}18.73 \\
(-0.45)\end{array}$ & 24 & $\begin{array}{c}21.36 \\
(0.24)\end{array}$ & 29 \\
\hline Financial (Banks) & $\begin{array}{c}20.33 \\
(0.92)\end{array}$ & 38 & $\begin{array}{l}20.72 \\
(-0.32)\end{array}$ & 34 \\
\hline Financial (Financial Services and Insurances) & $\begin{array}{c}19.14 \\
(-0.16)\end{array}$ & 24 & $\begin{array}{l}20.46 \\
(-0.44)\end{array}$ & 30 \\
\hline Healthcare & $\begin{array}{c}20.79 \\
(0.63)\end{array}$ & 11 & $\begin{array}{l}20.66 \\
(-0.17)\end{array}$ & 14 \\
\hline Industrial & $\begin{array}{c}20.54 \\
(1.05)\end{array}$ & 35 & $\begin{array}{c}22.58 \\
(1.50)\end{array}$ & 37 \\
\hline Technology \& Telecommunications & $\begin{array}{c}16.79 \\
(-1.96)\end{array}$ & 26 & $\begin{array}{c}19.63 \\
(-1.16)\end{array}$ & 31 \\
\hline Utilities & $\begin{array}{c}17.71 \\
(-1.26)\end{array}$ & 18 & $\begin{array}{l}20.47 \\
(-0.32)\end{array}$ & 17 \\
\hline Average Rating & 19.39 & 249 & 21.03 & 269 \\
\hline
\end{tabular}

Note: Table 1 gives an overview of the average rating of each sector in 2000 and 2001, respectively. $T$ statistics are stated in parentheses. The null hypothesis is that there is no significant difference between the sector mean and the sample mean.

effects seem to be rather small in the corporate governance ratings, it should be ensured that the results are neutral with respect to sector exposures. Besides, the financial data, such as stock returns, Tobin's q, ROE etc. might also be influenced by sector effects.

The financial data employed in the analysis are commonly used in academic research. These data were obtained from different Factset libraries, mainly from Worldscope. Whenever appropriate, financial data are used in the empirical analysis which were publicly available at the respective point in time to avoid look-ahead bias.

\section{Empirical analysis}

\section{Corporate governance and stock returns}

To analyse the impact of corporate governance on equity returns, value-weighted corporate governance factor portfolios were constructed. All firms were ranked on the basis of their corporate governance rating for the European Monetary Union (EMU) and the UK sample, respectively. For the EMU, the 20 per cent of companies with the highest corporate governance rating are assigned to the 'Good Governance Portfolio'. The bottom 20 per cent are allocated to the 'Bad Governance Portfolio'. For the UK, quartiles are built instead of quintile portfolios owing to the smaller size of the sample. The portfolio construction method deviates from that of Gompers et al. (2003). They construct their portfolios based on the absolute score of a firm while the portfolios in this study are determined by the relative score of a firm versus the complete sample. In this way, it is ensured that the portfolios are about equal with respect to total market capitalisation. 
Table 2 Country deviations

\begin{tabular}{|c|c|c|c|c|}
\hline Country & $\begin{array}{l}\text { Mean } 2000 \\
\text { ( } t \text { statistic) }\end{array}$ & $\begin{array}{l}\text { No. of } \\
\text { observations } \\
\text { in } 2000\end{array}$ & $\begin{array}{l}\text { Mean } 2001 \\
\text { (t statistic) }\end{array}$ & $\begin{array}{l}\text { No. of } \\
\text { observations } \\
\text { in } 2001\end{array}$ \\
\hline Belgium & $\begin{array}{l}15.16^{\star \star} \\
(-6.34)\end{array}$ & 8 & $\begin{array}{l}15.88^{\star \star} \\
(-6.90)\end{array}$ & 10 \\
\hline Denmark & $\begin{array}{l}12.46^{*} \\
(-3.29)\end{array}$ & 3 & $\begin{array}{r}14.89^{\star} \\
(2.96)\end{array}$ & 5 \\
\hline Finland & $\begin{array}{c}21.81 \\
(1.02)\end{array}$ & 4 & $\begin{array}{c}21.44 \\
(0.22)\end{array}$ & 5 \\
\hline France & $\begin{array}{l}17.94 \\
(-1.70)\end{array}$ & 40 & $\begin{array}{l}20.88 \\
(-0.12)\end{array}$ & 39 \\
\hline Germany & $\begin{array}{c}18.23 \\
(-1.20)\end{array}$ & 24 & $\begin{array}{l}19.75 \\
(-1.40)\end{array}$ & 26 \\
\hline Greece & $\begin{array}{l}16.42 \\
(-1.04)\end{array}$ & 3 & na & na \\
\hline Ireland & $\begin{array}{l}29.40^{\star \star} \\
(14.14)\end{array}$ & 4 & $\begin{array}{r}27.74^{*} \\
(4.79)\end{array}$ & 3 \\
\hline Italy & $\begin{array}{l}17.96^{\star} \\
(-2.04)\end{array}$ & 24 & $\begin{array}{l}19.03^{*} \\
(-2.57)\end{array}$ & 23 \\
\hline Netherlands & $\begin{array}{l}13.31^{\star \star} \\
(-7.53)\end{array}$ & 20 & $\begin{array}{l}15.45^{\star \star} \\
(-4.40)\end{array}$ & 18 \\
\hline Norway & $\begin{array}{l}\text { na } \\
(-)\end{array}$ & na & $\begin{array}{l}15.81 \\
(-2.38)\end{array}$ & 3 \\
\hline Portugal & $\begin{array}{c}8.80^{\star *} \\
(-14.89)\end{array}$ & 3 & $\begin{array}{l}\text { na } \\
(-)\end{array}$ & na \\
\hline Spain & $\begin{array}{l}13.92^{\star *} \\
(-8.91)\end{array}$ & 10 & $\begin{array}{l}14.47^{\star *} \\
(-7.43)\end{array}$ & 10 \\
\hline Sweden & $\begin{array}{l}18.68 \\
(-0.59)\end{array}$ & 19 & $\begin{array}{l}18.57^{\star} \\
(-2.16)\end{array}$ & 22 \\
\hline Switzerland & $\begin{array}{l}13.24^{\star \star} \\
(-4.50)\end{array}$ & 15 & $\begin{array}{l}14.28^{\star \star} \\
(-4.07)\end{array}$ & 15 \\
\hline UK & $\begin{array}{c}25.84^{\star \star} \\
(9.52)\end{array}$ & 71 & $\begin{array}{c}27.01^{\star *} \\
(8.96)\end{array}$ & 79 \\
\hline Average rating & 19.39 & 248 & 20.99 & 258 \\
\hline
\end{tabular}

Note: Table 2 presents the average rating of each country in 2000 and 2001, respectively. $T$ statistics are stated in parentheses. The null hypothesis is that there is no significant difference between the country mean and the sample mean.

${ }^{*}$ Significant at the 5 per cent level.

** Significant at the 1 per cent level.

From these portfolios, equally weighted returns to a zero investment strategy are computed. ${ }^{3}$ The investor is holding a long position in the 'Good Governance Portfolio' and a short position in the 'Bad Governance Portfolio'. Without any adjustments for market risk or differing firm characteristics, this zero-investment strategy leads to an annual return of 2.1 per cent for the EMU portfolio and 7.1 per cent for the UK portfolio from January 1997 to July 2002. Thus, a zero investment portfolio would have earned a positive return in both regions. The central question is whether this finding can be explained by market risk and other common factors determining common stock returns or whether it is attributable to differences in governance standards.

As documented by Fama and French (1992, 1993), stock returns are, next to market risk ('beta'), affected by a firm's market capitalisation ('size') and book-to-market ratio (BM) ('value' versus 'growth'). Jegadeesh and Titman (1993) showed that future returns might also be influenced by past returns ('momentum'). To account for these 
factors, the Carhart (1997) four-factor model is employed, which is estimated by

$$
\begin{aligned}
R_{\mathrm{LSt}}= & \alpha+\beta_{1}\left(R_{\mathrm{mt}}-R_{\mathrm{ft}}\right)+\beta_{2} S M B_{\mathrm{t}} \\
& +\beta_{3} H M L_{\mathrm{t}}+\beta_{4} M O M_{\mathrm{t}}+\varepsilon_{\mathrm{t}}
\end{aligned}
$$

where $R_{\mathrm{LSt}}$ is the monthly return of the zero-investment portfolio, $R_{\mathrm{mt}}$ is the monthly return on the market portfolio, and $R_{\mathrm{ft}}$ is the monthly risk-free interest rate. $S M B_{\mathrm{t}}$ (small minus big) is the monthly return on a size factor portfolio. $H M L_{\mathrm{t}}$ (high minus low) is the monthly return on a book-to-price factor-mimicking portfolio based on the book-to-market ratio. $M O M_{\mathrm{t}}$ (momentum) is the monthly return on a momentum factor portfolio. The constant alpha $(\alpha)$ represents the excess return an investor could have earned pursuing this investment strategy.

The factor portfolios SMB and HML are constructed following the method of Fama and French (1993). In line with the corporate governance portfolios, they are built value-weighted. The SMB portfolio is based on the firms' market capitalisation at the end of June. The companies with the lowest 30 per cent of market capitalisation are defined as 'small'. The top 30 per cent of firms are defined as 'big'. The return on the portfolio of 'big' companies is subtracted from the return on the small cap portfolio. The HML factor-mimicking portfolio is constructed in a similar way. The 30 per cent of companies with the highest BM are included in the "value portfolio'. The bottom 30 per cent are defined as 'growth portfolio'. The return on the growth portfolio is subtracted from the return on the value portfolio.

Momentum (MOM) is generally constructed as defined by Carhart (1997). To construct the MOM portfolio, the 30 per cent of firms with the highest 11-month returns lagged one month are classified as 'winners'. The bottom 30 per cent are classified as 'losers'. Each month, the return on the losers' portfolio is subtracted from the return on the winners' portfolio.

The results of estimating Equation (1) are shown in Table 3. The first row presents the regression estimates for the UK. As indicated by the alpha, the performance differential between the Good Governance and the Bad Governance Portfolios is about 6.8 per cent annually. With respect to size, value versus growth and momentum, the portfolios do not seem to differ substantially. The only significantly positive coefficient is $\beta_{1}$, which reveals that the Good Governance Portfolio has a higher exposure to market risk than the Bad Governance Portfolio has. The EMU results look very different from the UK results. The alpha decreases after adjusting for factor exposures from about 2.1 per cent to 1.6 per cent. A large part of the performance differential documented above can be attributed to differences in size, style and momentum. As shown by the positive value versus growth coefficient and the negative size coefficient, well-governed companies can be classified as large-cap value in the Eurozone. The highly significant HML coefficient indicates that sector effects might bias results. To sector adjust the returns of the corporate governance portfolios, the respective sector return IS subtracted from each firm's return and the market return added. The factor portfolios for this specification are constructed sector neutral. The results of sector-adjusted regressions, shown in Table 3 (row 3 and 4), support the proposition that sector exposures affected the results of the EMU sample. After sector adjusting, differences in style between the good and bad governance portfolio are eliminated. The HML coefficient basically equals zero. Further, 
Table 3 Performance evaluation regressions

\begin{tabular}{lccccc}
\hline & $\boldsymbol{\alpha}$ & $\boldsymbol{R}_{\mathbf{m}}-\boldsymbol{R}_{\mathbf{f}}$ & SMB & HML & MOM \\
\hline Style corrected & & & & & \\
UK & 6.83 & $0.25^{\star *}$ & -0.11 & -0.10 & -0.03 \\
EMU & $(1.32)$ & $(3.09)$ & $(-0.62)$ & $(-0.89)$ & $(-0.37)$ \\
& 1.58 & -0.04 & $-0.40^{\star *}$ & $0.46^{\star *}$ & $-0.15^{\star}$ \\
Style and sector corrected & $(0.36)$ & $(-0.78)$ & $(-3.08)$ & $(3.44)$ & $(-2.01)$ \\
UK & 4.63 & -0.02 & -0.15 & 0.19 & -0.04 \\
EMU & $(1.16)$ & $(-0.37)$ & $(-1.21)$ & $(1.49)$ & $(-0.30)$ \\
Style and country corrected & 2.97 & 0.06 & -0.22 & 0.04 & $-0.22^{*}$ \\
EMU & $(0.79)$ & $(1.35)$ & $(-1.88)$ & $(0.31)$ & $(-2.01)$ \\
& -1.04 & -0.04 & -0.12 & $0.59^{\star *}$ & -0.07 \\
& $(-0.26)$ & $(-0.85)$ & $(-1.00)$ & $(4.47)$ & $(-0.97)$ \\
\hline
\end{tabular}

Note: Table 3 shows the results of the performance evaluation regressions, Equation (1), for the EMU and UK sample respectively. Besides correction for style exposures using the Carhart model, sector and country effects are also adjusted for. $T$ statistics are stated in parentheses.

* Significant at the 5 per cent level.

** Significant at the 1 per cent level.

the alpha increases to about 3.0 per cent. The UK alpha declines to about 4.6 per cent after sector adjustments.

Since the descriptive statistics discussed earlier indicated that the corporate governance ratings exhibit significant country differences, country exposures of the portfolios are also adjusted for. To adjust the returns of the corporate governance factor portfolios for country effects, the same procedure is employed as previously in the sector-adjusted analysis. The respective country return is subtracted from each firm's return and the market return is added. While the sector returns are estimated based on the authors' own sample, the return of each country included in the EMU portfolios is represented by the respective MSCI country index. The reason is that the sample size for some countries is extremely small. For example, Portugal is represented in the 2000 portfolios with only three companies. Computing a country return from such few observations would not be a realistic proxy of the return of the country's stock market. Instead, the respective MSCI country index is used. As previously shown in the sector-adjusted analysis, the factor mimicking-portfolios for size (SMB), style (HML) and 12-months return MOM are also constructed country neutral. The results are presented in Table 3 (row 6). It is striking to see that the HML coefficient again becomes positive and highly significant. This indicates that sector effects again influence the results. The alpha reduces to about negative -1.0 per cent.

Overall, some evidence is found that corporate governance affects common stock returns positively. For the UK sample, the regression constants $(\alpha)$ are consistently positive, though statistically insignificant at the 5 per cent level. Comparing the present results for the UK with those of Gompers et al. (2003) for the US, it is observed that the size of the constants is similar. One main difference is that they were able to collect 10 years of data. To analyse whether the results are statistically significant as the number of observations increases, it would be worthwhile repeating the analysis when more years of data are available. This is also essential 
to examine the robustness of the conclusions.

For the EMU sample, the alphas are positive, though statistically insignificant, for most specifications. It seems that sector and country effects, which require more investigation, affect the EMU results. An avenue for further research would be to account for sector and country effects within one specification. This will be feasible as a longer time-series of governance ratings is available for Europe.

\section{Corporate governance and firm value}

If better-governed firms tend to have higher stock returns, this should in the long run, ceteris paribus, translate into a higher firm valuation. Consequently, the following investigates to what extent corporate governance is already accounted for in stock prices.

Tobin's $q\left(Q_{i t}\right)$ is used as the measure of firm valuation. Tobin's $q$ is defined as the market value of assets divided by the replacement value of assets. The market value of assets is represented by the sum of the book value of assets and the market value of common stock outstanding. From this, the sum of book value of common stock and balance sheet deferred taxes is subtracted. The replacement value of assets is represented by the book value of assets. Although there are more sophisticated measures of Tobin's q, this simple approximation is chosen to ensure data availability for most of the sample.

To separate the impact of corporate governance from other factors affecting Tobin's $q$, multivariate regression analysis is used. In line with Gompers et al. (2003) as well as Shin and Stulz (2000), the firms' book value of assets and the firms' age are accounted for. Further, Daines (2001) and Yermack (1996) showed that current and past performance significantly affect firm valuation. Therefore, the firms' ROE is included in the current and in the previous year as control variables. The following cross-sectional regression equation is estimated for every year $t$.

$$
\begin{aligned}
Q_{i t}= & \alpha+\beta_{1} C G_{i t}+\beta_{2} B V_{i t}+\beta_{3} A G E_{i t} \\
& +\beta_{4} R O E_{i t}+\beta_{5} R O E_{i(t-1)} \\
& +\beta_{5} S D_{i t}+\varepsilon_{i t}
\end{aligned}
$$

where $C G_{i t}$ is the logarithm of the firm's governance rating, $B V_{i t}$ is the logarithm of the book value of assets and $A G E_{i t}$ is the logarithm of the firms' age in years. The foundation of the firm is approximated by the first trading day. $R O E_{i t}$ and $R O E_{(t-1)}$ are the firm's ROE in the current and in the previous year, respectively. $S D_{i t}$ represents a vector of sector dummies. This regression equation is estimated annually from 1996 to 2001. Following Fama and MacBeth (1973), the time-series mean and $t$ statistics are computed from the annual regressions. As in the previous section, the equation is estimated separately for the two currency areas, the EMU and the UK.

Table 4 presents the results. In the EMU, the impact of corporate governance on firm value is rather strong. The coefficients of corporate governance are consistently positive in all annual regressions. The time-series coefficient is significantly positive at the 1 per cent level. On average, a 1 per cent increase in the corporate governance rating results in a 0.14 per cent increase in $Q$. The relationship between corporate governance and firm value is not nearly as strong in the UK. The time-series coefficient is statistically insignificant and close to zero. One possible explanation for the different results of the UK versus the EMU sample is that the EMU sample consists of several countries. It was found earlier in this paper that corporate governance 
Table 4 Corporate governance and firm value

\begin{tabular}{lccc}
\hline & \multicolumn{2}{l}{ Sector-adjusted results } & Country adjusted results \\
\cline { 2 - 4 } & EMU & UK & EMU \\
\cline { 2 - 4 } Year & CG coefficient & CG coefficient & CG coefficient \\
\hline \multirow{2}{*}{1996} & 0.13 & 0.09 & 0.25 \\
& $(0.89)$ & $(0.52)$ & $(1.44)$ \\
1997 & 0.17 & -0.03 & $0.38^{*}$ \\
& $(1.21)$ & $(-0.14)$ & $(2.25)$ \\
1998 & 0.14 & 0.23 & 0.05 \\
& $(0.98)$ & $(1.03)$ & $(0.30)$ \\
2099 & 0.13 & 0.13 & -0.17 \\
& $(0.85)$ & $(0.44)$ & $(-0.77)$ \\
2001 & 0.10 & -0.19 & -0.06 \\
& $(0.72)$ & $(-0.64)$ & $(-0.32)$ \\
Mean & 0.19 & -0.15 & 0.16 \\
& $(1.16)$ & $(-0.69)$ & $(1.00)$ \\
& $0.14^{* *}$ & 0.01 & 0.10 \\
& $(11.28)$ & $(0.18)$ & $(1.23)$ \\
\hline
\end{tabular}

Note: Table 4 shows the results of Equations (2) and (3). The results of Equation (1) are displayed in columns 1 and 2 for the EMU and the UK, respectively. Column 3 presents the results of Equation (3) for the EMU. The first six rows display the annual coefficients of corporate governance (CG). The last row presents the time-series statistics. $T$ statistics are stated in parentheses.

* Significant at the 5 per cent level.

** Significant at the 1 per cent level.

standards differ significantly between countries. Therefore, the strong CG coefficient observed in the EMU could be due to country effects, which have previously been documented by LaPorta et al. (1999). To investigate this possibility further, Equation (2) is re-estimated including country dummies:

$$
\begin{aligned}
Q_{i t}= & \alpha+\beta_{1} C G_{i t}+\beta_{2} B V_{i t}+\beta_{3} A G E_{i t} \\
& +\beta_{4} R O E_{i t}+\beta_{5} R O E_{i(t-1)} \\
& +\beta_{5} C D_{i t}+\varepsilon_{i t}
\end{aligned}
$$

where $C D_{i t}$ represents a vector of country dummies. All other variables are defined as in Equation (2). The results presented in Table 4 (column 3) are more ambiguous than the sector-adjusted findings. Despite the fact that the time-series coefficient is still positive and reasonable in size, it is not statistically significant. Four of the annual coefficients are positive, of which one is statistically significant at the 5 per cent level. Two are negative, though insignificant.
Overall, these results indicate that firm valuation is positively related to the quality of governance standards in the EMU. This relationship is rather strong before country adjusting and becomes weaker after accounting for country differences.

\section{Corporate governance and firm performance}

There are, generally speaking, two reasons why good corporate governance increases firm value. First, good governance increases investor trust. Investors might perceive well-governed firms as less risky and apply a lower expected rate of return, which leads to a higher firm valuation. Secondly, as shown for example by Jensen and Meckling (1976), better-governed firms might have more efficient operations, resulting in a higher expected future cash-flow stream. This section examines the impact of corporate governance on operating efficiency as approximated by the NPM 
Table 5 Corporate governance and firm performance: EMU

\begin{tabular}{lll}
\hline Year & $\begin{array}{l}\text { NPM } \\
\text { CG coefficient }\end{array}$ & $\begin{array}{l}\text { ROE } \\
\text { CG coefficient }\end{array}$ \\
\hline 1996 & -0.12 & -0.08 \\
& $(-1.12)$ & $(-0.96)$ \\
1997 & -0.17 & -0.08 \\
1998 & $(-1.61)$ & $(-0.90)$ \\
& $-0.20^{\star}$ & -0.05 \\
1999 & $(-2.01)$ & $(-0.55)$ \\
2000 & -0.06 & 0.04 \\
& $(-0.61)$ & $(0.38)$ \\
2001 & -0.10 & -0.11 \\
& $(-1.11)$ & $(-1.21)$ \\
Mean & -0.03 & -0.12 \\
& $(-0.41)$ & $(-1.68)$ \\
& $-0.14^{* *}$ & $-0.07^{\star}$ \\
& $(-4.44)$ & $(-2.94)$ \\
\hline
\end{tabular}

Note: Table 5 shows the results of Equations (4) and (5) for firms incorporated in the EMU. The results of Equation (4) are displayed in column 1. Column 2 presents the results of Equation (5). The first six rows display the annual coefficients of corporate governance (CG). The last row presents the time-series statistics. $T$ statistics are stated in parentheses.

* Significant at the 5 per cent level.

${ }^{* \star}$ Significant at the 1 per cent level.

$\left(N P M_{i t}\right)$ and $\operatorname{ROE}\left(R O E_{i t}\right)$. Exactly as in the previous parts, the sample is split into firms incorporated in the EMU and UK firms. In line with Gompers et al. (2003), the following regression equation is estimated for every year $t:^{4}$

$$
\begin{gathered}
N P M_{i t}=\alpha+\beta_{1} C G_{i t}+\beta_{2} B M_{i t} \\
+\beta_{3} \mathrm{SD}_{\mathrm{it}}+\varepsilon_{i t}
\end{gathered}
$$

where $C G_{i t}$ is the firm's corporate governance rating, $B M_{i t}$ is the logarithm of the BM and $S D_{i t}$ is a vector of sector dummies. The regression equation employing $R O E_{i t}$ as measure of performance is

$$
\begin{gathered}
R O E_{i t}=\alpha+\beta_{1} C G_{i t}+\beta_{2} B M_{i t} \\
+\beta_{3} S D_{i t}+\varepsilon_{i t}
\end{gathered}
$$

where all explanatory variables are defined as in Equation (4). These regressions are estimated annually from 1996 to 2001. Following Fama and MacBeth (1973), the time-series mean and $t$ statistics are computed.

Table 5 presents the results of the EMU sample. Contradicting expectations, the time-series coefficients of corporate governance are significantly negative. In the ROE regressions, the annual corporate governance coefficients are all negative, though insignificant. For NPM, five out of six CG coefficients are negative. In the UK, the results do not provide evidence of a relationship between corporate governance and performance. As shown in Table 6, both the time-series coefficients are negative, but they are statistically insignificant. Further, the annual coefficients do not display a clear pattern. While there are several possible explanations why a relationship between corporate governance and performance in the UK cannot be found, the EMU results are puzzling. Prior to suggesting possible explanations, it is investigated whether the EMU results are biased by country effects. Therefore, regression Equations (4) and (5) were re-estimated including country dummies instead of sector dummies:

$$
\begin{gathered}
N P M_{i t}=\alpha+\beta_{1} C G_{i t}+\beta_{2} B M_{i t} \\
+\beta_{3} C D_{i t}+\varepsilon_{i t}
\end{gathered}
$$


Table 6 Corporate governance and firm performance: UK

\begin{tabular}{lcc}
\hline Year & NPM & ROE \\
& CG coefficient & CG coefficient \\
\hline 1996 & -0.83 & 0.02 \\
& $(-0.55)$ & $(0.18)$ \\
1997 & -0.75 & -0.22 \\
& $(-0.49)$ & $(-1.46)$ \\
1998 & -0.61 & 0.08 \\
& $(-0.38)$ & $(0.81)$ \\
1999 & 0.32 & 0.10 \\
& $(0.20)$ & $(0.76)$ \\
2000 & 0.00 & -0.06 \\
& $(0.02)$ & $(-0.38)$ \\
2001 & 0.01 & 0.07 \\
& $(0.04)$ & $(0.60)$ \\
Mean & -0.31 & -0.00 \\
& $(-1.58)$ & $(-0.05)$ \\
\hline
\end{tabular}

Note: Table 6 shows the results of Equations (4) and (5) for the UK The results of Equation (4) are displayed in column 1. Column 2 presents the results of Equation (5). The first six rows display the annual coefficients of corporate governance (CG). The last row presents the time-series statistics. $T$ statistics are stated in parentheses.

${ }^{*}$ Significant at the 5 per cent level.

** Significant at the 1 per cent level.

and

$$
\begin{aligned}
R O E_{i t}= & \alpha+\beta_{1} C G_{i t}+\beta_{2} B M_{i t} \\
& +\beta_{3} C D_{i t}+\varepsilon_{i t}
\end{aligned}
$$

where $C D_{i t}$ is a vector of country dummies and all other variables are defined as in Equations (4) and (5) above.

As Table 7 shows, the inclusion of country dummies does not substantially alter the findings with respect to the EMU sample. Despite the fact that the ROE time-series coefficient of corporate governance is no longer statistically significant, the time-series coefficients of corporate governance remain negative for both specifications. Further, the CG coefficient in the NPM regression is still significantly negative at the 1 per cent level.

Overall, the results with respect to the relationship between corporate

governance and firm performance in the Eurozone are contrary to expectations. One possible explanation could be that accounting numbers are biased measures of firm performance. Both proxies are based on reported accounting earnings. A negative correlation between earnings and corporate governance possibly implies that badly governed companies report less conservative earnings estimates. As recent corporate scandals showed, managers tend to use their latitude to overstate earnings. Obviously, this hypothesis requires further investigation.

\section{Conclusions and implications}

This paper analysed the relationship between different governance standards and stock returns, firm value and operating performance for most firms included in the FTSE Eurotop 300 in 2000 and 2001. Although a limited history of corporate governance ratings was available, the results give first insights regarding the impact of corporate governance in Europe.

When the evidence on the relationship between corporate governance and firm value as well as equity returns is 
Table 7 Corporate governance and firm performance: EMU (regressions including country dummies)

\begin{tabular}{lll}
\hline & NPM & ROE \\
\hline Year & CG coefficient & CG coefficient \\
\hline \multirow{2}{*}{1996} & -0.10 & 0.06 \\
& $(-0.83)$ & $(0.68)$ \\
1997 & -0.15 & -0.08 \\
& $(-1.22)$ & $(-0.82)$ \\
1998 & -0.17 & 0.01 \\
& $(-1.50)$ & $(0.13)$ \\
1999 & -0.12 & 0.02 \\
& $(-1.02)$ & $(0.21)$ \\
2000 & -0.00 & -0.12 \\
2001 & $(-0.01)$ & $(-1.10)$ \\
& -0.02 & -0.04 \\
Mean & $(-0.22)$ & $(-0.46)$ \\
& $-0.09^{\star *}$ & -0.02 \\
& $(-3.33)$ & $(-0.88)$ \\
\hline
\end{tabular}

Note: Table 7 shows the results of Equations (6) and (7) for the EMU. The results of Equation (6) are displayed in column 1. Column 2 presents the results of Equation (7). The first six rows display the annual coefficients of corporate governance (CG). The last row presents the time-series statistics. $T$ statistics are stated in parentheses.

* Significant at the 5 per cent level.

** Significant at the 1 per cent level.

combined, substantial differences are found between the UK market and the Eurozone markets. While economically large excess returns to a zero-investment corporate governance strategy in the UK were found, no evidence was found of a relationship between governance and firm valuation. This result indicates that the UK market is still adjusting. In the long run, the excess returns to corporate governance should translate into a higher firm valuation for better-governed firms. In the EMU, the excess returns to a corporate governance strategy were much smaller, particularly after correcting for country effects. Instead, a stronger relationship was found between governance and firm value. This evidence might imply that current corporate governance standards have, to a large extent, already been incorporated in stock prices. The reason why investors in Eurozone companies already accounted more for a firm's governance standards than UK investors did could be explained by the fact that Eurozone countries traditionally tend to have poorer governance standards. This result is in line with prior empirical research discussed above, which also demonstrated that the lower the governance standards, the stronger the relationship between governance and firm value.

\section{Acknowledgments}

The authors would like to thank Roderick Molenaar for constructing the factor portfolios and his helpful suggestions throughout the research process.

Additionally, Vishal Jadnanansing's help in obtaining the financial data is appreciated. The authors are grateful for the comments of Mathijs van Dijk, Jeroen Derwall, Christian Kerckhoffs and Dariusz Wojcik and thank Deminor Rating, Brussels, for providing the corporate governance ratings. Finally, the authors wish to thank Style Research Ltd for providing the factor portfolios. All remaining errors are the authors' sole responsibility.

\section{Notes}

1 McKinsey and Company, July 2002, McKinsey Global Investor Opinion Survey on Corporate Governance, Key Findings, Exhibit 1, 3 and 4, available on: www.mckinsey.com

2 The authors are aware that this procedure will introduce look-ahead bias and survivorship bias in the analysis, but given the constrained data history, extending the ratings backwards is perceived as the best possible solution. To reduce the impact of these biases on the results, the time period is limited to a maximum of four years. 
3 Equally weighted instead of value-weighted returns were computed to avoid larger companies determining the findings.

4 Differing from Gompers et al. (2003), the authors use the current year BM. The main problem inherent in the corporate governance data is survivorship bias. Hence, using the current year BM minimises this problem compared with the use of lagged accounting data. Since the main purpose of this analysis is to find out whether corporate governance has an impact on performance as measured by ROE and NPM and not how good investors' prediction skills are, this should not severely affect the conclusions. Another difference between the present analysis and that of Gompers et al. (2003) is that the present sample is truncated to mitigate the impact of outliers. Gompers et al. (2003) perform median-deviation regressions instead.

\section{References}

Adams, R. B. and Hamid, M. (2002) 'Board Structure and Banking Firm Performance', Working Paper, available in Social Science Research Network Electronic Library, <http://papers.ssrn.com>

Black, B. (2001) 'Does Corporate Governance Matter? A Crude Test Using Russian Data', University of Pennsylvania Law Review, 149, 2131-50.

Carhart, M. M. (1997) 'On Persistence in Mutual Fund Performance', Journal of Finance, 52(1), 57-82.

Daines, R. (2001) 'Does Delaware Law Improve Firm Value?', Journal of Financial Economics, 62, 525-58.

De Jong, A., DeJong, D. V., Mertens, G. and Wasly, C. E. (2001) 'The Role of Self-Regulation in Corporate Governance: Evidence from the Netherlands', Working Paper, available in Social
Science Research Network Electronic Library, $<$ http://papers.ssrn.com>.

Drobetz, W., Schillhofer, A. and Zimmermann, H. (2004) 'Corporate Governance and Expected Stock Returns: Evidence from Germany', European Financial Management, 10, 267-293.

Fama, E. F. and French, K. R. (1992) 'The Cross Section of Expected Stock Returns', Journal of Finance, 47, 427-65.

Fama, E. F. and French, K. R. (1993) 'Common Risk Factors in Stock and Bond Returns', Journal of Financial Economics, 33, 3-56.

Fama, E. F. and MacBeth, J. (1973) 'Risk, Return, and Equilibrium: Empirical Tests', Journal of Political Economy, 81, 607-36.

Gompers, A., Ishii, J. L. and Metrick, A. (2003) 'Corporate Governance and Equity Prices', Quarterly Journal of Economics, 118, 107-55.

Jegadeesh, N. and Titman, S. (1993) 'Returns to Buying Winners and Selling Losers: Implications for Stock Market Efficiency', Journal of Finance, 48, 65-91.

Jensen, M. C. and Meckling, W. H. (1976) 'Theory of the Firm: Managerial Behavior, Agency Costs and Ownership Structure', Journal of Financial Economics, 3, 305-60.

LaPorta, R., Lopez-de-Silanes, F., Shleifer, A. and Vishny, R. (1999) 'Investor Protection and Corporate Valuation', Working Paper 7403, NBER, Cambridge, MA.

Shin, H.-H. and Stulz, R. M. (2000) 'Firm Value, Risk, and, Growth Opportunities', Working Paper 7808, NBER, Cambridge, MA.

Yermack, D. (1996) 'Higher Market Valuation of Companies with a Small Board of Directors', Journal of Financial Economics, 40, 185-211. 
Copyright of Journal of Asset Management is the property of Henry Stewart Publications and its content may not be copied or emailed to multiple sites or posted to a listserv without the copyright holder's express written permission. However, users may print, download, or email articles for individual use. 